\title{
À propos de la bédouinisation en Afrique du Nord
}

\author{
Jacques Vignet-Zunz
}

\section{OpenEdition}

Journals

Édition électronique

URL : https://journals.openedition.org/tc/1040

DOI : $10.4000 /$ tc. 1040

ISSN : 1952-420X

Éditeur

Éditions de l'EHESS

Édition imprimée

Date de publication : 1 juin 1983

ISSN : 0248-6016

Référence électronique

Jacques Vignet-Zunz, «À propos de la bédouinisation en Afrique du Nord », Techniques \& Culture [En ligne], 1 | 1983, mis en ligne le 26 janvier 2006, consulté le 29 septembre 2022. URL : http:// journals.openedition.org/tc/1040 ; DOI : https://doi.org/10.4000/tc.1040

Ce document a été généré automatiquement le 29 septembre 2022.

Tous droits réservés 


\section{À propos de la bédouinisation en Afrique du Nord}

Jacques Vignet-Zunz 